\title{
Approaches to Inclusive Pedagogy: A Systematic Literature Review
}

\author{
Anabel Moriña
}

Seville University, c/ Pirotecnia, s/n, ES-41013 Seville, Spain, anabelm@us.es

\begin{abstract}
The paper presents a systematic review of inclusive pedagogy; it differences between inclusive education, inclusive practice, and inclusive pedagogy; the pedagogic approach adopted integrates four elements: beliefs, knowledge, design and actions; further research is needed to determine what teachers do, how, and why they do it.
\end{abstract}

Keywords: inclusive pedagogy, diversity, teachers, faculty members, systematic literature review.

\section{Introduction}

The terms inclusive education, inclusive practice, and inclusive pedagogy are often used interchangeably in the literature. They are not, however, synonyms. In a recent work, Black-Hawkins (2017) explained the differences between the three concepts. Inclusive education is related to the political, social and cultural processes that take place in schools. Ainscow et al. (2006), Messiou (2017) and Slee (2018) all view inclusive education as a process which maximises learning and increases the engagement of all students. This concept is opposed to that of special education, which categorises students with SEN and, on many occasions, denies them the opportunity to participate and share educational and social experiences with their peers in ordinary contexts (Slee, 2018). In contrast, inclusive education refers to efforts to reduce exclusion in school curricula, cultures, and communities. It is perhaps the broadest of the three concepts, since the starting point for both inclusive practices and inclusive pedagogy is the acknowledgment of inclusive education (Florian, 2015a). 
For its part, inclusive practice refers to the actions carried out by teachers ${ }^{1}$ in order to give meaning to their understanding of inclusive education. In other words, it refers exclusively to teaching practices which foster the learning and engagement of all students, thereby reducing marginalisation. Examples of inclusive practice include cooperative learning (Kagan \& Kagan, 2009), 'lesson study' (Simon et al., 2018), or peer tutoring (Topping, 2015).

The third concept, on which this systematic literature review focuses, is inclusive pedagogy. Unlike the notion of inclusive practice, inclusive pedagogy does not refer exclusively to teaching actions, but rather encompasses other teaching skills also. From the perspective of inclusive pedagogy, all decisions made are seen as being determined not only by teachers' knowledge, competence and actions, but also by their values and beliefs regarding students and the nature of teaching and learning, as well as social processes and influences (Alexander, 2004). Conceptually, inclusive pedagogy has been defined as an approach to teaching and learning in which teachers respond to learners' individual differences, in order to avoid excluding certain students (Florian, 2014).

Indeed, Florian (2015b) has suggested that the starting point for developing inclusive pedagogy would be the recognition that every learner is different and that learning must be improved for all students. This approach argues that everyone can learn when the conditions are suitable.

In order to develop inclusive pedagogy, teachers first need to acquire a set of skills to enable them to facilitate processes of inclusion in their classrooms. According to Forlin (2001), teachers need a series of skills, attitudes, and knowledge in order to do their job from this perspective. Rouse (2009), however, argues that one of the main barriers to developing inclusion is precisely the fact that the majority of teachers do not have the knowledge, skills or attitudes required by their profession. This stance is closely linked to the analysis carried out in 2004 by Shulman, who argued that teacher training should encompass three key learning elements: 1) the head (knowledge and theoretical basis of the profession); 2) the hand (skills, techniques, and practices); and 3) the heart (ethical and moral dimensions, attitudes, and beliefs that are crucial to the profession). Following Shulman's proposal (2004), Rouse (2009) suggested that inclusion depends on what teachers' 'know' (about theoretical, political and legal questions), 'do' (moving from knowledge to action) and 'believe' (about their capacity to teach all students). Florian (2014) later revisited these ideas, proposing an inclusive pedagogy model focused on what, how and why teachers engage in inclusive pedagogy.

The works cited so far all refer to pre-university educational stages. However, the concept of inclusive pedagogy has also been adopted in the context of higher education. Indeed, Gale and Mills (2013) identified three dimensions underpinning inclusive

1 Throughout this article it used the generic term 'teacher' to refer to education professionals working at all levels of the education system, from primary all the way up to university level. 
pedagogy in the university context: beliefs, designs, and actions. Thus, a fourth element can be added to the analysis model proposed by Rouse (2009) and Florian (2014) for inclusive pedagogy, namely design or planning.

In this sense, the framework of analysis for inclusive pedagogy adopted in this article comprises beliefs, knowledge, design and actions. Firstly, in this pedagogical approach, there is a belief that all students are valuable and have something to contribute to the teaching and learning process. Diversity is seen as an opportunity to improve learning processes (Shields, 2000). This component of the inclusive pedagogy model is perhaps the most complex, since changing beliefs or attitudes is no easy task (Rouse, 2017). Nevertheless, it is important to establish initiatives to try and do just this, since studies such as the ones by Tiwari et al. (2015), Van Houtte and Demanet (2016) have concluded that successful inclusion depends on the development of a positive attitude by teachers. These same studies also found that teachers' beliefs regarding students' teachability contribute to preventing dropout.

On the knowledge dimension, Rouse (2009) underlines the need for teachers to be familiar with teaching strategies; disability and special needs; how children learn; what the child needs to learn; classroom organisation; where to go for help when needed; how to identify and assess difficulties; how to evaluate and monitor children's learning; and the legal context of education. It should be pointed out here that, while it is important to provide teachers with this content-based knowledge, the evidence suggests that it alone is not enough to improve practice since many teachers fail to apply what they have learned after the end of the training course. One issue that arises in relation to this, therefore, is the question of how to organise in-service training for teachers. From the perspective of inclusive pedagogy, training is best provided in the workplace, in collaboration with and based on the specific needs of the teachers themselves (Spear \& Da Costa, 2018).

The other dimension is the design of a pedagogy that recognizes the difference, and the planning of actions that really respond to the needs of all students (Gale \& Mills, 2013). The belief that all students have something valuable to contribute to the learning environment prompts a pedagogical design that includes and makes the most of these knowledge bases. From this perspective, all subjects should be designed, right from the very start, to try and satisfy the educational needs of as many students as possible. They should also be as accessible as possible, thereby minimising the need to make adjustments later on, in order to respond to each students' specific requirements (Sandoval et al., 2020). Within this dimension, the best option seems to be to plan in accordance with the precepts of universal design for learning (Lawrie et al., 2017; Ok et al., 2017), prioritising a proactive, rather than a reactive response.

The final element is linked to the actions or practices that 'work with' rather than 'act on' students and their communities (Gale \& Mills, 2013). Some studies focusing on actions based on inclusive pedagogy suggest a number of ways of achieving this, including flexible learning, student-centred learning, and teachers who encourage students to 
share their beliefs, knowledge, and experiences (Aguirre et al., 2020; Melero et al., 2020; Moriarty, 2007). Others suggest that teaching for inclusion means developing actions based on universal design for learning (Evans et al., 2015; Sanahuja et al., 2020), in which there is room for all students. Moreover, according to Waitoller and Thorius (2016), any curriculum which does not take diversity into consideration in its design is, by definition, 'disabling'. Some authors propose a different set of pedagogic strategies which seek to involve all students, such as visual representations, cooperative learning activities, research-based approaches (including simulations), problem-based learning, work projects, and the use of new technologies (Evans et al., 2015). In general terms, pedagogic methods need to be varied (Seatter \& Ceulemans, 2017) and focused on fostering constructivist learning through the active engagement of learners (Nie \& Lau, 2010).

In addition to methodological strategies, this last dimension also includes an emotional and affective component which is related to the way in which teaching is carried out (Moriña, 2020). Studies have therefore concluded that effective teaching methods, while necessary, are not the only key aspect, and that positive interactions between teachers and their students are also of crucial importance, along with the worry expressed by the former about the latter (Scott et al., 2003). There are clear benefits when teachers know their pupils (Arnaiz et al., 2019; Ouellett, 2004) and in this sense, teachers are invited to make personal relationships with their students and to develop motivational strategies (Scott et al., 2003).

In short, diversity, as it is understood by inclusive pedagogy, is a common element in both inclusive education and inclusive practice. What inclusive pedagogy contributes is an approach focused entirely on teachers, although not only on their teaching actions but also on their social actions, beliefs, knowledge, and designs. The systematic review presented in this article offers an overview of what is known about inclusive pedagogy at all educational stages. The article analyses all existing evidence, with no time constraints. It aims to fill a void in the literature, since no other study to date has undertaken a systematic review of this particular topic.

\section{Method}

Systematic literature reviews are an organised and systematic method for selecting and critically analysing research (Petticrew \& Roberts, 2006). The procedure followed in this article involved six steps. First, the research questions were raised. Then, the descriptors for the search were defined and the databases for the study were selected. Thirdly, the inclusion and exclusion criteria were defined. Fourth, the scientific quality of the publications was analysed using predefined quality criteria. Only studies that met the quality requirements were included in the study. Fifth, data answering the research questions were extracted. Finally, a thematic analysis of the studies was carried out. 


\section{Research Questions}

Four questions guided this review:

1) What is the map of evidence on inclusive pedagogy in terms of country, research methodology, educational stage, and date of publication?

2) What exactly has been researched in relation to the inclusive pedagogical approach (beliefs, knowledge, design, and actions)?

3) How has inclusive pedagogy been used in teacher training?

4) Which teaching and learning strategies foster inclusive pedagogy?

\section{Literature Search Descriptors and Databases}

The descriptors for this study were: 'inclusive pedagogy' and the combination of 'inclusive pedagogy' and 'education', 'school', 'primary education', 'elementary education', 'secondary education', 'high school', 'higher education', 'university', 'college' or 'tertiary education'. These descriptors were entered in the search engines of three scientific databases: ERIC, Scopus and Web of Science.

\section{Inclusion and Exclusion Criteria}

In this study the inclusion criteria were:

1. The study was peer-reviewed, to ensure that it met a minimum standard of quality and reliability in the view of other scholars.

2. The article was published in English.

3. The article included the keywords, with no restrictions in terms of date of publication.

4. Inclusive pedagogy was viewed as a pedagogical approach based on what is done, as well as how and why.

5. The article focused on inclusive pedagogy in any educational stage.

Three exclusion criteria were established: the article used the concept of inclusive pedagogy but with a meaning different from that represented by the pedagogical approach on which this article is based (i.e. the study had a different aim); the study had been published in other types of publications (books or book chapters and conference papers); and the article adopted an exclusively theoretical approach to the meaning of inclusive pedagogy or did not provide any kind of implication for educational practice. 


\section{Document Selection}

The initial searches identified 190 potential publications in the three databases selected (duplicated studies were eliminated). All the abstracts were screened for inclusion and exclusion criteria. Articles for which there was doubt as to their pertinence were also ordered for further examination. An exhaustive analysis identified 41 articles that satisfied the inclusion criteria. These 41 full articles were downloaded and read. After analysing all 41 articles in accordance with these criteria, 23 were finally selected for the analysis of inclusive pedagogy.

\section{Review}

Based on the research questions, a matrix was designed to systematise the analysis of each of the selected papers and facilitate comparisons between them. The first part of the matrix noted authorship, publication year, country, and educational stage. The second part recorded information about the study, including aims, type of study, data collection instruments, and a number of participants. The final section focused on main findings and conclusions.

\section{Analysis}

The articles were sorted into categories by means of a thematic analysis which encompassed the following themes: country, educational stage, research methodology, inclusive pedagogical approach, teacher training, and teaching strategies for inclusive pedagogy. Each article was individually analysed and coded according to these established categories. This analysis allowed the four research questions to be answered.

\section{Results}

The vast majority of the studies employed qualitative research methods, with the exception of two quantitative works (Higbee, 2009; Woodcock \& Hardy, 2017) and three based on a mixed design (Barrington, 2004; Moriarty, 2007; Sheehy \& Budiyanto, 2015). All articles were published from 1996 onwards. The majority were conducted in the United Kingdom $(n=9)$, the United States $(n=5)$, and South Africa $(n=3)$. The rest were all carried out in a single country (Australia, Canada, Indonesia, New Zealand and Thailand), with the exception of the study by Burnard et al. (2008), which was an international work conducted jointly in Australia, Spain, Sweden, and the UK.

In relation to the educational stage on which the studies focused, the majority centred on primary education $(n=12)$, with 6 focusing on university teaching and 5 on secondary education. The remaining two studies did not specify this information. 
All articles were published between 1996 (Winiarcyk \& Long, 1996) and 2018 (Majoko, 2018), although most of the research was carried out between 2014 and 2017.

As regards the topics analysed, three main categories were identified: an inclusive pedagogical approach, inclusive pedagogy in teacher training, and methodological strategies for inclusive pedagogy.

\section{The Inclusive Pedagogical Approach: What to Do, and Why and How to Do it}

Firstly, those studies focused on the inclusive pedagogical approach $(\mathrm{n}=12)$ were studied, in terms of what is done, and why and how. The first study identified was by Ammah and Hodge (2005), in which the authors aimed to describe the beliefs and practices of secondary-school physical education teachers regarding the inclusion and teaching of students with severe disabilities. Participants were two teachers with secondary school experience. Three recurring issues emerged from the results: (a) wavering beliefs; (b) inclusion is complex; and (c) troubled confidence. The conclusion drawn was that, in order to engage with confidence in inclusive pedagogy, it is important for teachers to feel properly trained and supported and to have the necessary resources.

Subsequently, this time in the field of higher education, Moriarty (2007) conducted a study to explore the use of inclusive pedagogy among members of the Science, Technology, Engineering, and Mathematics Faculties. The aim was to identify obstacles to adopting inclusive teaching methods for diverse students and students with disabilities, and to propose ways of overcoming them. The most significant barriers identified for the development of inclusive pedagogy were the lack of an inclusive mindset, lack of knowledge regarding pedagogy, high teaching loads and lack of time to develop new methods. The study also observed a relationship between beliefs, knowledge and environment factors, which helped teachers develop inclusive pedagogy.

Burnard (2008) carried out a study on music teachers in UK secondary schools and their beliefs about inclusive pedagogy and approaches to inclusive teaching and learning. Interviews were used to explore music teachers' perceptions of what they believe they do in responding to the challenge of re-engaging disaffected youth. The findings highlighted the fact that inclusive pedagogies imply more than the accumulation of teaching strategies. Rather, they work hard to forge connections with students and find new ways of responding to their needs, building democratic relationships both in and outside the classroom, and rethinking teachers' roles.

In a similar vein, but this time focusing on four different countries (Spain, Australia, Sweden, and the UK), Burnard et al. (2008) explored ways of working with young people on the margins of society, looking at how teachers development a learning context in which students can succeed musically. The challenge seemed to lie in teachers' ability to strategically (rather than just tactically) focus on the musical experience as a means of building common ground between community cultures and values. In this study, as in 
the previous one by Burnerd (2008), the relationship between teachers and students was found to be extremely important.

In 2011 and 2012, two studies were published as part of the same research project: Florian and Black-Hawkins (2011) and Black-Hawkins and Florian (2012). These studies aimed to explore teachers' craft knowledge of what constitutes inclusive practice, in terms of what they do and why and how they do it. The results identified several practical examples of inclusive education. And, also, highlighted the fact that teachers wishing to use inclusive pedagogy to ensure the academic achievement of all students are faced with a number of challenges and dilemmas in their everyday practice. The practice of class teachers was often varied in nature, and can be considered to be based on the standards of inclusive pedagogy. The study highlighted two strategies based on inclusive pedagogy: work choice and play zone.

For his part, Makoelle (2014) interviewed six secondary-school teachers who engaged in inclusive pedagogy. The main findings reported by the study indicated that there is no universally-accepted definition of inclusive pedagogy; rather, it's meaning is contextually, philosophically, and operationally determined. The study showed that further research is required to redefine the idea of inclusive pedagogy. In this article, inclusive pedagogy referred to all teaching methods, approaches, means and principles aimed at improving student engagement. Moreover, it was assumed that inclusive pedagogy also encompassed beliefs and conceptions regarding what constitutes inclusive teaching and learning. In this sense, the pedagogical approach adopted was more constructivist.

In 2015, Moscardini presented the results of a study with a group of 12 teachers from special primary schools for children with moderate learning difficulties. The study explored teachers' knowledge and beliefs about the process of teaching and learning mathematics in relation to children with moderate learning difficulties. The findings revealed that, prior to the training course, participants had limited knowledge of children's mathematical development, with teaching often being based on intuition and out dated practices. The majority of teachers had low expectations of children with learning difficulties. Following the intervention, participants rethought their attitudes and claimed that a better understanding of children's mathematical thinking provided a more secure knowledge base for teaching. They also acknowledged the extent to which learners were limited by existing classroom practices. The study concluded that the pedagogical decisions made by teachers were prompted by complex interactions between knowledge, beliefs and contextual factors.

Sheehy and Budiyanto (2015) researched the pedagogic orientations of teachers working in the context of inclusive education. The findings suggested that, in general, the implicit teachers' orientation was a social constructivist one. The study concluded that the majority of participants believed that all children learned in the same way and were the responsibility of all teachers. This in turn was linked to a belief in children's right to receive education alongside their peers. In general, what these authors discovered was 
that all teachers believed they could teach all children, an attitude that constitutes a solid basis for supporting the development of inclusive practice in the classroom.

Slightly later, but also in 2015, Spratt and Florian (2015) studied a cohort of graduates from a one-year Professional Graduate Diploma in Education. The article explores how newly-qualified teachers (in their first year as probationary teachers) used the ideas of inclusive pedagogy. The authors also aimed to determine whether or not teachers who had completed their studies and were working in a school environment actually put the concept of inclusive pedagogy into practice in their classrooms. The study concluded that there was a common belief among participants in the benefits of valuing the participation of each individual. When the real techniques used by teachers were examined, it was found that inclusive pedagogy did not offer a completely new set of practices; the teachers were using, for example, collaborative group work, formative assessment, and student choice. These findings provide additional evidence that an inclusive pedagogic approach cannot be reduced to a simple list of 'how to' tips. Rather, inclusive pedagogy requires teachers to make careful decisions, rooted in sound professional knowledge, in order to offer opportunities for everyone in the classroom learning community to participate and engage in the learning process.

Two years later, Florian and Beaton (2017) carried out a study on the inclusive pedagogic approach in response to questions regarding how students could gain access to the additional support they required without being treated differently from their peers. The article presented a case taken from a broader exploratory study designed to explore the role of pupil voice in both self-assessments and teachers' formative assessments of learning. The study was designed to expand on previous work carried out in relation to the concept of inclusive pedagogy, which had emphasised the importance of the teacherpupil relationship. The aim was to work in collaboration with teachers and students to deepen our sociocultural understanding of inclusive pedagogy, focusing on the studentpupil interaction more than on teaching or school practices, which had previously been the focus of analysis in the other studies cited in this section (for example, the one by Spratt \& Florian, 2015). This study analysed teacher and student assessment practices and explored how teachers used what they learned from listening to their pupils. For their part, the students trusted their teachers to listen to them and chose to participate in activities that were meaningful to them as students, thus bestowing true meaning on the concept of inclusion.

The last study analysed in the inclusive pedagogic approach category was by Nind and Lewthwaite (2018). These authors proposed applying the lens of inclusive pedagogy to research methods pedagogy. The results revealed that while participants had an extensive knowledge of research methods, the main challenge was how to develop their knowledge of pedagogic content. In other words, the challenge was how to make their expert knowledge accessible (i.e. teachable and learnable) to students. Many of the approaches to the teaching of social research methods described by participants were 
designed to ensure that learners not only acquired knowledge of research methods, but also gained experience in them. The data revealed references to learning through action, student-centred learning, active learning and problem-based learning. Moreover, participants also learned how to connect with learners and developed competences in relation to research methods. Many participating practitioners made an effort to ensure that their practices were inclusive. The study concluded that the discourse, culture and evidence base for both inclusive pedagogy and the pedagogy of research methods needs further development, and that despite a lack of articulated inclusive pedagogy, examples exist of inclusive pedagogy within the field of social science research methods.

\section{Inclusive Pedagogy in Teacher Training}

This section outlines five articles which focused on analysing teacher training through teacher education courses for both novel and experienced practitioners, based on the precepts of inclusive pedagogy. In 2010, Florian and Linklater carried out a study of a new initial teacher education course based on the idea that, rather than asking whether teachers have the necessary knowledge and skills to teach in inclusive classrooms, the real question we should be asking is how to help them make the most of what they already know when their students encounter barriers. Based on the cases of primary school teachers and secondary school teachers, it concluded that by creating learning environments in which available opportunities were used to improve everyone's achievement, newly-qualified teachers became inclusive professionals. The study emphasized the potential for surprise and its value for understanding the significance of what teachers think about how learning opportunities are to all students.

The second work in this section is by Walton and Lloyd (2012). The study described the development and implementation of a postgraduate course in inclusive education. The authors argued that one of the challenges linked with the implementation of inclusive education is the effective recruitment of teachers to satisfy the diverse learning needs in their classrooms. The course provided training in inclusive teaching strategies appropriate for all students in a classroom. The assessments carried out revealed a high level of satisfaction with the course among participants. The difficulties encountered by both students and teachers when attempting to implement inclusive pedagogies may be explained as challenges associated with change. The article concluded that teachers needed to develop a collaborative, classroom-based practice of inclusive knowledge through the implementation of and reflection and theorisation on inclusive pedagogies.

The third study is by Florian and Spratt (2013). This article examined the development and use of an analytical framework for exploring the practice of newly-qualified mainstream teachers graduated from a one-year Professional Graduate Diploma in Education that was based on a concept of inclusive pedagogy. Participants were seven newly-qualified teachers, four from primary and three from secondary education. The study was located in a social constructivist paradigm, assessing and attempting to understand participants' 
actions and views and acknowledging the complexity of the environment in which they work. A key question for the research team was: how can we recognise inclusive pedagogy when we see it? Instead of offering a 'how to' guide to inclusion, the course provided students with an environment in which to question their practice within their own context, with the aim of fostering a kind of inclusive pedagogy which responded to the individual needs of all students in their classrooms.

Majoko (2016) carried out a study of 24 pre-service teachers' understanding, attitudes, training, and concerns regarding inclusion in early childhood education. The aim of the study was to research the training received by teachers in inclusive pedagogy. Participants understood and held positive attitudes to inclusion, but felt poorly prepared and somewhat reluctant to implement it. They also identified contextual social and cultural difficulties to its practice. In accordance with the precepts of inclusive pedagogy, participants' ideas about inclusion were based on the need to guarantee the participation and performance of all children, including those with special educational needs or those requiring additional support. Some participants, however, focused on disabilities rather than abilities.

Woodcock and Hardy (2017) saw inclusive pedagogy as being designed to help correct the external causes of educational inequality. One striking finding was that for those teachers who had participated in some kind of formal training course or workshop but had not attained a specialist qualification, inclusion was seen as problematic, although just as importantly, the training was also found to foster empathy and commitment. The study concluded that in order to cultivate positive understandings of and beliefs regarding inclusion, greater attention must be paid to training in inclusive pedagogical approaches that would allow teachers to become agents for inclusion.

The final work in this section is by Klibthong and Agbenyega (2018). In this study, the authors describe the development of a Special Education professional development partnership program with an Australian inclusive school. The program was based on the Inclusive Pedagogical Approach in Action (Spratt \& Florian, 2015). Sixteen early childhood teachers from Thailand participated in the program. The purpose of the study was to analyse how the professional experience of teachers is transformed in relation to being, knowing, and becoming an inclusive teacher. The study concluded that participants in the program improved knowledge and actions on inclusive pedagogy. According to this work, the program can transform conceptions about special educational needs and influence the elimination of negative beliefs about the possibilities of learning and ability of certain children.

\section{Methodological Strategies for Inclusive Pedagogy}

The last five articles analysed focused on describing a set of methodological strategies for inclusive pedagogy. These strategies were (in chronological order of publication of the articles): service learning, online learning activities, multiple intelligence, universal instructional design, and digital stories. Although numerous references to these strategies 
can be found in the scientific literature, in this review we focused only on those works which directly alluded to how they can be used to foster inclusive pedagogy.

The earliest work identified in the systematic review falls into this category (Winiarcyk \& Long, 1996). Indeed, it is in this study that the concept of inclusive pedagogy was mentioned for the first time, although it was not fully defined. Winiarcyk and Long described service learning as a strategy for achieving inclusive pedagogy. For these authors, the strategy is seen as a learning experience for both students and teachers.

Subsequently, McLoughlin (2001) focused on online learning activities as an opportunity for developing inclusive pedagogy. For this author, the key is for students to learn in an environment which offers them multiple perspectives, since this enables them to think critically, communicate better, and solve problems. Teaching approaches focused on online communities provide just such an environment. According to McLoughlin, an inclusive curriculum would be the first step towards planning online learning activities, which in turn would contribute to ensuring active, constructive, collaborative, intentional, conversational, and reflexive learning.

Barrington (2004) proposed and explained why multiple intelligence theory should be considered an inclusive pedagogy which may help improve teaching and learning in HE. In his work, he suggested that universities had been too slow to accommodate diversity in their teaching and learning strategies, and argued that multiple intelligence should be seen as an inclusive pedagogy because its vision of intelligence is very broad and it aims to teach and evaluate students who use more than two types of intelligence. This in turn enables students to make the most of their own strengths, and prevents them from being side lined by having to focus exclusively on traditional forms of learning.

In turn, Higbee (2009) proposed Universal Instructional Design (UID) as a practice for inclusive pedagogy, suggesting that it be governed by the following guiding principles: a) developing a friendly and supportive classroom climate for learning; b) identify the main components of a course or programme; c) communicating clear objectives; d) choosing teaching methods that take into account diverse learning styles, abilities, ways of working and previous experiences; e) exploring the use of natural supports for learning, including technology, to enhance opportunities for all learners; f) considering multiple opportunities for students to showcase their knowledge; $g$ ) offering constructive feedback; and h) facilitating relationships between teachers and students. All are fundamental strategies for good teaching. The study concluded that although developing UID may involve extra time in previous course planning stages, it eventually saves time and eliminates the need to make accommodations once the course has started.

The final article analysed in this section was by Vinogradova et al. (2011), who explored the power of English language learners' digital stories as student-centred projects. The study offered practical recommendations for language teachers concerned with experimenting with digital storytelling, and outlined pedagogical practices and digital storytelling in the light of current research into inclusive pedagogy, communities of practice and 
multiliteracies. Using examples of students' digital stories, journal entries, final essays and interviews, the authors identified the classroom as a community of practice in which several fields of expertise are recognised and shared.

\section{Discussion and Conclusions}

Inclusive pedagogy is a teaching and learning approach focused on beliefs, knowledge, design and actions, through which teachers strive to, include all the students (Florian, 2014; Gale \& Mills, 2013; Rouse, 2009). These four elements are vital to gaining insight into what inclusive teachers and faculty members do, and how and why they do it (Slee, 2018). However, in the systematic review carried out on inclusive pedagogy, we found no studies focusing on the full model of analysis proposed in this article. Partial evidence was detected, however, with half the studies analysed focusing on the pedagogic approach as constituted by the beliefs, knowledge, and actions of inclusive pedagogy. However, only five articles analysed all three dimensions (Black-Haukins \& Florian, 2012; Florian \& Black-Haukins, 2011; Moscardini, 2015, Moriarty, 2007; Nind \& Lewthwaite, 2018), while the rest focused solely on beliefs (Burnard, 2008; Sheehy \& Budiyanto), knowledge (Woodcock \& Hardy, 2017) or actions (Burnard et al., 2008; Florian \& Beaton, 2018; Spratt \& Florian, 2015), or alternatively, beliefs and actions together (Ammah \& Hodge, 2005; Makoelle, 2014).

Nevertheless, we believe it is important for studies also to contemplate the design or planning dimension, since as the literature has shown (Eilam, 2017; Ramirez et al., 2016), this is the first step towards action and should be taken into consideration in order to ensure a high-quality response in student teaching and learning processes.

Thus, the systematic review identified a gap in existing research into inclusive pedagogy. Further studies are required which analyse beliefs, knowledge, design, and actions (both methodological and affective and social) from a holistic perspective. Moreover, there is no specific education level on which more emphasis should be placed, since although studies are more frequent in primary schools $(n=9)$, this framework of analysis has not been used previously in any educational stage.

The data presented in the majority of studies were gathered in Western countries, particularly the UK and the USA. Thus, it would also be beneficial for further research to be conducted in non-Western and Southern countries.

Another aspect to highlight is that the majority of the articles analysed used a qualitative methodology. This seems to be the most effective approach and suggests that future research should strive to explore teaching skills using qualitative techniques, mainly interviews and observations. This recommendation also applies to the analysis of teachers' beliefs and attitudes, despite the fact that these aspects have mainly been studied to date using quantitative methods (for example, Srivastava et al., 2016, or Subban \& Mahlo, 
2017). The existence of studies, which use qualitative methods to explore attitudes and beliefs towards the idea of including all students, shows that such aspects can indeed be effectively analysed from this perspective.

In terms of approaches to pedagogy, our study reveals four common approaches identified in the different works. A first approach refers to teachers having an inclusive belief, as they consider it their obligation to teach all their students, without exception (Makaolle, 2014; Moriarty, 2007; Sheely \& Buyidanto, 2015). This is in line with what was advocated in the last UNESCO world report (2020) "all mens all". Another approach refers to the importance of the preparation of teachers and how teachers who develop an inclusive pedagogy are trained in inclusive education (Ammah \& Hodge, 2005; Moriarty, 2007). A third approach is that inclusive teachers use a variety of methodological strategies based on constructivism (Florian \& Black-Hawkins, 2011; Makaolle, 2014; Sheely \& Buyidanto, 2015). Finally, other studies recognise that inclusive pedagogy is more than just teaching strategies and those connections and relationships with students are fundamental to promoting learning (Burnard, 2008; Burnard et al., 2008). In fact, we know that in order to contribute to student learning, not only effective teaching methods are necessary, but also the concern shown towards students, personal connections or respect (Moriña, 2019). From this point of view, the emotional and affective component of how one teaches and learns is fundamental (Postareff et al., 2017). Therefore, training policies should include actions to prepare teachers in this sense. In addition, more studies are needed that address the analysis of inclusive pedagogy from the action component, exploring both methodological and affective strategies.

Although inclusive pedagogy has been studied from the teachers' perspective, there is a clear lack of analysis focused on students' voices. Only one article identified in the systematic review took the student's perspective into account (Florian \& Beaton, 2018).This prompts us to conclude that not only is more research required into inclusive pedagogy in general, but that said research should strive to include other voices also. Understanding what teachers do, and how they do it, from the students' perspective, may provide extremely valuable information for gaining insight into the key elements of the teaching and learning process that foster inclusion. Other authors have concluded that the voice of students is a powerful lever for improving educational practices and for advancing towards inclusion (Canning, 2017; Dare \& Nowicki, 2018).

As regards teacher training in inclusive pedagogy, although there is evidence that reflects the importance of training in this field and demonstrates the high level of satisfaction felt by participants after attending courses of this nature (for example, Walton \& Lloyd, 2012), due to the small number of articles focusing on this question $(n=5)$ and their content, we are unable to draw any firm conclusions regarding what form this training should take. This may constitute a possible avenue of future research, with studies focusing on the design, development and assessment of training courses in inclusive pedagogy. Teacher training, including pedagogy, as described in this systematic review, 
transforms (Klibthong \& Agbenyega, 2018) and has an immediate impact on the learning of all students. In line with the analysis carried out in this article, teacher training should be diverse and multifaceted. Knowledge is needed about how to teach, but also about how to interact with students, or how to connect with them emotionally and affectively.

One final idea that should be highlighted is linked to the methodological strategies which foster inclusive pedagogy. Only five strategies were identified in the review: service learning, online learning activities, multiple intelligence, UID and digital stories. We believe there are many more, although due to the rigour of the systematic review carried out, and considering the descriptors used for searching the databases, only those presented in this article were linked to the concept of inclusive pedagogy. If we had used 'inclusive practice' instead of 'inclusive pedagogy' as our keyword, then it is likely that many other works would have emerged in relation to methodological strategies. However, analysing this question would require another systematic review, rather than the one proposed here.

In any case, of the strategies presented in this review, the UID is particularly powerful. Therefore, so that the curriculum is not exclusive (Carballo et al., 2019), the teaching staff must design the subjects for everyone. To this end, among other aspects, the materials must be varied and in different formats, or the evaluations must be diverse and accessible.

Finally, based on the systematic review carried out, we can conclude that inclusive pedagogy is an emerging area of research that deserves closer attention from the research community. Future studies may contribute to ensuring that educational environments take proactive action and strive to ensure the social and educational engagement of all students, not only those with special educational needs. Inclusive pedagogy may reduce dropout rates and improve the academic success of all students. Understanding which beliefs, knowledge, designs, and actions prompt teachers to engage in inclusive pedagogy may encourage others to follow their example, providing a scientific foundation for what to do to ensure that all educational environments are as inclusive as possible.

\section{Limitations}

This paper has two limitations which should be acknowledged. First, few articles have been published on inclusive pedagogy in higher education, and this may have limited the review carried out. And second, since some of the articles reviewed described the results with more information than others (for example, some works failed to specify the educational stage on which the study focused), some relevant data may be missing from the study carried out. 


\section{Acknowledgements}

This work was supported by the Ministry of Economy and Competitiveness of Spain, State Research Agency and FEDER funds European Union [grant numbers EDU2016-76587-R].

\section{References}

Aguirre, A., Carballo, R. \& Lopez-Gavira, R. (2020). Improving the academic experience of students with disabilities in higher education: faculty members of Social Sciences and Law speak out, Innovation: The European Journal of Social Science Research, 1-16. doi: 10.1080/13511610.2020.1828047

Ainscow, M., Booth, T., \& Dyson, A. (2006). Improving schools, developing inclusion. London, UK: Routledge.

Alexander, R. (2004). Still no pedagogy? Principle, pragmatism and compliance in primary education. Cambridge Journal of Education, 34(1), 7-33. doi: 10.1080/0305764042000183106

Ammah, J. O., \& Hodge, S. R. (2005). Secondary physical education teachers' beliefs and practices in teaching students with severe disabilities: A descriptive analysis. The High School Journal, 89(2), 40-54. doi: 10.1353/hsj.2005.0019

Arnaiz, P., De Haro, R., \& Maldonado, R. (2019). Barriers to students learning and participation in an inclusive school as perceived by future education professionals. Journal of New Approaches in Educational Research, 8(1), 18-24. doi: 10.7821/naer.2019.1.321

Barrington, E. (2004). Teaching to student diversity in higher education: How multiple intelligence theory can help. Teaching in Higher Education, 9(4), 421-434. doi: 10.1080/1356251042000252363

Black-Hawkins, K. (2017). Understanding inclusive pedagogy: Learning with and from teachers. In V. Plows \& B. Whitburn (Eds.). Inclusive education. Making sense of everyday practice (pp. 13-30). Rotterdam, The Netherlands: Sense Publishers.

Black-Hawkins, K., \& Florian, L. (2012). Classroom teachers' craft knowledge of their inclusive practice. Teachers and Teaching Education, 18(5), 567-584. doi: 10.1080/13540602.2012.709732

Booth, A. (2001, May 14-16). Cochrane or cock-eyed? How should we conduct systematic reviews of qualitative research? [Conference presentation] Qualitative Evidence-based Practice Conference, Taking a Critical Stance. Coventry University. http://www.leeds.ac.uk/educol/ documents/00001724.htm

Burnard, P. (2008). A phenomenological study of music teachers' approaches to inclusive education practices among disaffected youth. Research Studies in Music Education, 30(1), 59-75. doi: $10.1177 / 1321103 X 08089890$

Burnard, P., Dillon, S., Rusinek, G., \& Saether, E. (2008). Inclusive pedagogies in music education: A comparative study of music teachers' perspectives from four countries. International Journal of Music Education, 26(2), 109-126. doi: 10.1177/0255761407088489 
Carballo, R., Morgado, B., \& Cortés-Vega, M.D. (2019). Transforming faculty conceptions of disability and inclusive education through a training programme. International Journal of Inclusive Education, 1-17. doi: 10.1080/13603116.2019.1579874

Canning, J. (2017). Conceptualising student voice in UK higher education: four theoretical lenses. Teaching in Higher Education, 22(5), 519-531. doi: 10.1080/13562517.2016.1273207

Dare, L., \& Nowicki, E. (2018). Strategies for inclusion: Learning from students' perspectives on acceleration in inclusive education. Teaching and Teacher Education, 69, 243-252. doi: S0742051X17306789

Gale, T., \& Mills, M. (2013). Creating spaces in higher education for marginalised Australians: Principles for socially inclusive pedagogies. Enhancing Learning in the Social Sciences, 5(2), 7-19. doi: http://dx.doi.org/10.11120/elss.2013.00008

Gast, I., Schildkamp, K., \& Van der Veen, J. T. (2017). Team-based professional development interventions in higher education: a systematic review. Review of Educational Research, 87(4), 736-767. doi: 10.3102/0034654317704306

Eilam, B. (2017). Probing teachers' lesson planning: promoting metacognition. Teachers College Record, 119(13), 1-28. http://www.tcrecord.org

Evans, C., Muijs, D., \& Tomlinson, M. (2015). Engaged student learning. High-impact strategies to enhance student achievement. York, UK: Higher Education Academy.

Gale, T., Mills, C., \& Cross, R. (2017). Socially inclusive teaching: belief, design, action as pedagogic work. Journal of Teacher Education, 68(3), 345-356. doi: 10.1177/0022487116685754

Florian, L. (2014). What counts as evidence of inclusive education? European Journal of Special Needs Education, 29(3), 286-295. doi: 10.1080/08856257.2014.933551

Florian, L. (2015a). Inclusive Pedagogy: A transformative approach to individual differences but can it helps reduce educational inequalities? Scottish Educational Review, 47(1), 5-14. doi: 10.1080/13540602.2012.709732

Florian, L. (2015b). Conceptualising inclusive pedagogy: The inclusive pedagogical approach in action. In J. M. Deppeler, T. Loreman, R. Smith \& L. Florian (Eds.), Inclusive Pedagogy Across the Curriculum, volume 7 (pp. 11-24). Melbourne, AU: Emerald Group Publishing Limited. Florian, L., \& Beaton, M. (2018). Inclusive pedagogy in action: getting it right for every child. International Journal of Inclusive Education, 22(8), 870-884. doi: 10.1080/13603116.2017.1412513

Florian, L. \& Black-Hawkins, K. (2011). Exploring inclusive pedagogy. British Educational Research Journal, 37, 813-828. doi:10.1080/01411926.2010.501096

Florian, L., \& Linklater, H. (2010). Preparing teachers for inclusive education: using inclusive pedagogy to enhance teaching and learning for all. Cambridge Journal of Education, 40(4), 369-386. doi: 10.1080/0305764X.2010.526588

Florian, L., \& Spratt, J. (2013). Enacting inclusion: A framework for interrogating inclusive practice. European Journal of Special Needs Education, 28(2), 119-135. https://doi.org/10.10 80/08856257.2013.778111

Forlin, C. (2001). Inclusion: Identifying potential stressors for regular class teachers. Educational Research, 43 (3), 235-245. doi: 10.1080/00131880110081017 
Higbee, J. L. (2009). Implementing universal instructional design in postsecondary courses and curricula. Journal of College Teaching and Learning, 6(8), 65-77. doi: https://doi.org/10.19030/ tlc.v6i8.1116

Hitch, D., Macfarlane, S., \& Nihill, C. (2015). Inclusive pedagogy in Australian universities: A review of current policies and professional development activities. The International Journal of the First Year in Higher Education, 6(1), 135-145. doi: http://dx.doi.org/10.5204/intjfyhe.v6i1.254

Kagan, S., \& Kagan, M. (2009). Kagan cooperative learning. San Clemente, CA: Kagan Publishing. Klibthong, S., \& Agbenyega, J. S. (2018). Exploring professional knowing, being and becoming through inclusive pedagogical approach in action (IPAA) Framework. Australian Journal of Teacher Education, 43(3), 108-123. doi: http://dx.doi.org/10.14221/ajte.2018v43n3.7

Lawrie, G., Marquis, E., Fuller, E., Newman, T., Qiu, M., Nomikoudis, M., Roelofs, F., \& van Dam, L. (2017). Moving towards inclusive learning and teaching: a synthesis of recent literature. Teaching \& Learning Inquiry, 5(1), 1-13. doi: http://dx.doi.org/10.20343/ teachlearninqu.5.1.3

Majoko, T. (2016). Inclusion in early childhood education: pre-service teachers voices. Early Child Development and Care, 186(11), 1859-1872. doi: 10.1080/03004430.2015.1137000

Makoelle, T. M. (2014). Pedagogy of inclusion: a quest for inclusive teaching and learning. Mideterranean Journal of Social Sciencies, 5(20), 1259-1267. doi: 10.5901/mjss.2014.v5n20p1259

McLoughlin, C. (2001). Inclusivity and alignment: Principles of pedagogy, task and assessment design for effective cross-cultural online learning. Distance Education, 22(1), 7-29. doi: 10.1080/0158791010220102

Melero, N., Domenech, A., \& Cabeza-Ruiz, R. (2020). Beliefs and actions of university lectureres of Sports Sciences and Physical Activity regarding students' learninng motivation. Pedagogika, 137(1), 45-60. https://doi.org/10.15823/p.2020.137.3

Messiou, K. (2017). Research in the field of inclusive education: time for a rethink? International Journal of Inclusive Education, 21(2), 146-159. doi: 10.1080/13603116.2016.1223184

Moriarty, M. A. (2007). Inclusive pedagogy: teaching methodologies to reach diverse learners in science instruction. Excelence and Equity Education, 40, 252-265. doi: 10.1080/10665680701434353

Moriña, A. (2019). The keys to learning for university students with disabilities: Motivation, emotion and faculty-student relationships. PLoS ONE 14(5): e0215249. https://doi.org/10.1371/ journal.pone.021524

Moriña, A. (2020). Faculty members who engage in inclusive pedagogy: Methodological and affective strategies for teaching. Teaching in Higher Education. https://doi.org/10.1080/1356 2517.2020.1724938

Moscardini, L. (2015). Primary special school teachers' knowledge and beliefs about supporting learning in numeracy. Journal of Research in Special Educational Needs, 15(1), 37-47. doi: 10.1111/1471-3802.12042

Nie, Y., \& Lau, S. (2010). Differential relations of constructivist and didactic instruction to students' cognition, motivation and achievement. Learning \& Instruction, 20(5), 411-423. doi: https:// doi.org/10.1016/j.learninstruc.2009.04.002 
Nind, M., \& Lewthwaite, S. (2018). Hard to teach: inclusive pedagogy in social science research methods education. International Journal of Inclusive Education, 22(1), 74-88. doi: 10.1080/13603116.2017.1355413

Ok, M. W., Rao, K., Bryant, B. R., \& McDougall, D. (2017). Universal design for learning in pre-K to rrade 12 classrooms: A systematic review of research. Exceptionality, 25(2), 116-138. doi: 10.1080/09362835.2016.1196450

Orr, A., \& Hamming, S. (2009). Inclusive postsecondary strategies for teaching students with learning disabilities: a review of literature. Learning Disability Quarterly, 32(3), 181-197. doi: $10.2307 / 27740367$

Ouellett, M. L. (2004). Faculty development and universal instructional design. Equity \& Excellence in Education, 37(2), 135-144. doi: 10.1080/10665680490453977

Petticrew, M., \& Roberts, H. (2006). Systematic reviews in the social sciences: practical guide. Malden, US: Blackwell Publishing.

Postareff, L., Mattsson, M., Lindblom-Ylänne, S., \& Hailikari, T. (2017). The complex relationship between emotions, approaches to learning, study success and study progress during the transition to university. Higher Education: The International Journal of Higher Education Research, 73(3), 441-457. doi: https://doi.org/10.1007/s10734-016-0096-7

Ramirez, E., Clemente, M., Martín-Domínguez, J., \& Rodríguez, I. (2016). Planning and doing in professional teaching practice. A study with early childhood education teachers working with ICT (3-6 years). Early Childhood Educational Journal, 45(5), 713-725. doi: 10.1007\%2Fs10643016-0806-X

Rouse, M. (2009). Developing inclusive practice: a role for teachers and teacher education. Education in the North, 16, 6-13.

Rouse, M. (2017). A role for teacher and teacher education in developing inclusive practice. In M. Etherington (Ed.). What teacher need to know (pp. 19-35). Eugene, US: Wipp \& Stock.

Sanahuja, A., Moliner, O., \&. Moliner, L. (2020). Inclusive and democratic practices in primary school classrooms: A multiple case study in Spain. Educational Research. 62(1), 111-127. doi: 10.1080/00131881.2020.1716631

Sandoval, M., Morgado, B., \& Domenech, A. (2020). University students with disabilities in Spain: faculty beliefs, practices and support in providing reasonable adjustments, Disability \& Society, 1-20. doi: 10.1080/09687599.2020.1751078

Scott, S. S., Loewen, G., Funckes, C., \& Kroeger, S. (2003). Implementing universal design in higher education: moving beyond the built environment. Journal on Postsecondary Education and Disability, 16, 78-89. Retrieved from http://www.ahead.org/publications/jped/vol_16

Seatter, C. S., \& Ceulemans, K. (2017). Teaching sustainability in higher education: pedagogical styles that make a difference. The Canadian Journal of Higher Education, 47(2), 47-70. Retrieved from http://journals.sfu.ca/cjhe/index.php/cjhe/article/view/186284

Sheehy, K., \& Budiyanto. (2015). The pedagogic beliefs of Indonesian teachers in inclusive schools. International Journal of Disability, Development and Education, 62(5), 469-485. doi: 10.1080/1034912X.2015.1061109 
Simon, C., Echeita, G., \& Sandoval, M. (2018). Incorporating students' voices in the 'Lesson Study' as a teacher-training and improvement strategy for inclusion. Cultura \& Education, 30(1), 205-225. doi: https://doi.org/10.1080/11356405.2017.1416741

Shields, C. M. (2000). Learning from difference: Considerations for schools as communities. Curriculum Inquiry, 30(3), 275-294. https://doi.org/10.1111/0362-6784.00166

Shulman, L. S. (2004). The wisdom of practice: Essays on teaching, learning, and learning to teach. San Francisco, US: Jossey-Bass, Inc.

Slee, R. (2018). The inclusive education workbook: Teaching, learning and research in the irregular school. London, UK: Routledge.

Spears, A. M., \& Da Costa, R. B. (2018). Potential for transformation? Two teacher training programs examined through a critical pedagogy framework. Teaching and Teacher Education, 69, 202-209. doi: https://doi.org/10.1016/j.tate.2017.10.013

Spratt, J., \& Florian, L. (2015). Inclusive pedagogy: From learning to action. Supporting each individual in the context of 'everybody'. Teaching and Teacher Education, 49, 89-96. doi: http://dx.doi.org/10.1016/j.tate.2015.03.006

Srivastava, M., De Boer, A. A., \& Pijl, S. J. (2016). Preparing for the inclusive classroom: Changing teachers' attitudes and knowledge. Teacher Development, 21(4), 561-579. doi: /10.1080/13664530.2017.1279681

Subban, P., \& Mahlo, D. (2017). 'My attitude, my responsibility' Investigating the attitudes and intentions of pre-service teachers toward inclusive education between teacher preparation cohorts in Melbourne and Pretoria. International Journal of Inclusive Education, 21(4), 441-461. doi: 10.1080/13603116.2016.1197322

Tiwari, A., Ajay Das, A., \& Manisha Sharma, M. (2015). Inclusive education a "rhetoric" or "reality"? Teachers' perspectives and beliefs. Teaching and Teacher Education, 52, 128-136. doi: http://dx.doi.org/10.1016/j.tate.2015.09.002

Topping, K. (2015). Peer tutoring: old method, new developments. Infancia \& Aprendizaje, 38(1), 1-29. doi: https://doi.org/10.1080/02103702.2014.996407

UNESCO (2020). Global Education Monitoring Report - Inclusion and education: All means all. Paris: Unesco.

Van Houtte, M., \& Demanet, J. (2016). Teachers' beliefs about students, and the intention of students to drop out of secondary education in Flanders. Teaching and Teacher Education, 54, 117-127. doi: http://dx.doi.org/10.1016/j.tate.2015.12.003

Vinogradova, P., Linville, H. A., \& Bickel, B. (2011). "Listen to my story and you will know me": digital stories as student-centered collaborative projects. TESOL Journal, 2(2), 173-202. doi: 10.5054/tj.2011.250380

Waitoller, F. R., \& Thorius, K. A. K. (2016). Cross-pollinating culturally sustaining pedagogy and universal design for learning: toward an inclusive pedagogy that accounts for dis/ability. Harvard Educational Review, 86(3), 366-389. doi: 10.17763/1943-5045-86.3.366 
Walton, E., \& Lloyd, G. (2012). From clinic to classroom: A model of teacher education for inclusion. Perspectives in Education, 30(2), 62-70. Retrieved from https://www.questia.com/ library/journal/1P3-3455870941/from-clinic-to-classroom-a-model-of-teacher-education Winiarcyk, E., \& Long, T. (1996). Navigating through community service learning approaches. Thresholds in Education, 22(2), 2-6. https://eric.ed.gov/?id=EJ539153

Woodcock, S., \& Hardy, I. (2017). Probing and problematizing teacher professional development for inclusion. International Journal of Educational Research, 83, 43-54. doi: http://dx.doi. org/10.1016/j.ijer.2017.02.008

\title{
Inkliuzinès pedagogikos požiūriai: sisteminè literatūros apžvalga
}

\author{
Anabel Morińa
}

Sevilijos universitetas, c / Pirotecnia, s / n, ES-41013 Sevilija, Ispanija, anabelm@us.es

\section{Santrauka}

Šis tyrimas atliktas siekiant apžvelgti tai, kas yra žinoma apie inkliuzinę pedagogiką visoje švietimo sistemoje. Straipsnyje analizuojama pagal porinę apžvalgą (angl. peer review) recenzuota mokslinė literatūra apie inkliuzinę pedagogiką. Iš viso rasta 190 straipsnių, kuriuose aprašyti ịvairūs inkliuzinės pedagogikos aspektai. Iš jų 23 atitiko nustatytus kriterijus ir buvo peržiūrèti. Analizuojami straipsniai buvo suskirstyti ị kategorijas, apimančias šias temas: šalis, ugdymo etapas, metodika, inkliuzinès pedagogikos požiūris, mokytojų rengimas ir inkliuzinės pedagogikos mokymo strategijos. Atlikus sisteminę apžvalgą aprašomi inkliuzinès pedagogikos srityje atlikti tyrimai, taip siekiant padidinti mūsų dabartinị supratimą, ką mokytojai / dèstytojai daro siekdami įtraukti visus mokinius į mokymąsi ir kaip bei kodèl tai daro. Analizuojama, kuo skiriasi inkliuzinis ugdymas, inkliuzine praktika ir inkliuzinè pedagogika. Čia pedagoginis požiūris apima keturis elementus: įsitikinimus, žinias, sumanymus ir veiksmus. Rezultatai išryškina faktą, kad visuose švietimo lygiuose reikalingi tolesni tyrimai, kad būtų galima išanalizuoti inkliuzinę pedagogiką praktikuojančių mokytojų / dèstytojų ịsitikinimus, žinias, sumanymus ir veiksmus.

Esminiai žodžiai: inkliuzinè pedagogika, įvairové, mokytojai, dèstytojai, fakulteto nariai, sisteminga literatūros apžvalga. 